\title{
Atrial natriuretic peptide-induced stimulation of cyclic GMP formation by isolated bovine luteal cells*
}

\author{
B. Brunswig, L. T. Budnik and A. K. Mukhopadhyay \\ Institute for Hormone and Fertility Research, Grandweg 64, 2000 Hamburg 54, FRG
}

\begin{abstract}
Summary. Incubation of bovine luteal cells with an atrial natriuretic peptide (rat atriopeptin II, rAP-II) did not affect hCG-stimulated or basal cyclic AMP accumulation and progesterone production, but cyclic GMP formation was stimulated by rAP-II in a dose-dependent manner, being maximally stimulatory in the nanomolar range. This stimulatory influence of $\mathrm{rAP}$-II on cyclic GMP formation results from a specific stimulation of particulate guanylate cyclase. We suggest that, although rAP-II mediated cyclic GMP formation can be demonstrated in bovine luteal cells, there appear to be no acute effects of the atrial peptide on the regulation of progesterone production by these cells.
\end{abstract}

Keywords: atrial natriuretic peptide; luteal cells; steroidogenesis; guanylate cyclase; cow

\section{Introduction}

Mammalian atrial cardiocytes are known to produce and secrete a family of peptides called atrial natriuretic peptide (ANP), having potent natriuretic, diuretic and vasorelaxant properties (Cantin \& Genest, 1985; Anderson \& Bloom, 1986). Apart from their classical role in the regulation of cardiovascular homoeostasis, these peptides have also been shown to modulate the function of a variety of steroidogenic tissues. ANP inhibits basal as well as hormone-stimulated aldosterone production by rat and bovine adrenoglomerulosa cells (Kudo \& Baird, 1984; Racz et al., 1985) and progesterone production in mouse Leydig tumour cells (Pandey et al., 1985). However, a stimulation of steroidogenesis in response to ANP was observed in mouse Leydig cells (Bex \& Corbin, 1985; Pandey et al., 1986; Mukhopadhyay et al., 1986a, 1988) and in human granulosa cells (Pandey et al., 1987). No influence of ANP on either testosterone or cyclic AMP production was detected in rat Leydig cells, although a stimulation of cyclic GMP formation in response to ANP was observed (Mukhopadhyay et al., 1986b). Similarly, in rat luteal cells no effect of ANP could be demonstrated on cyclic AMP accumulation or progesterone production although an activation of guanylate cyclase was reported (Budnik et al., 1987). Although the general effects of ANP in steroidogenic tissues remain conflicting, stimulation of cyclic GMP by ANP seems to be common in all tissues so far examined. This stimulation always appears to result from a specific activation of a particulate guanylate cyclase activity (Waldman et al., 1984; Tremblay et al., 1985). Vollmar et al. (1988) have reported that a significant quantity of ANP could be measured in an acidic extract of bovine corpus luteum tissue and that a single class of high-affinity receptors for ANP was present in this tissue; the authors suggested that ANP may play a role in the regulation of luteal steroidogenesis, but this possibility has not been examined. We have therefore investigated the effect of ANP on cyclic nucleotide formation and progesterone production in luteal cells from cows.

\footnotetext{
${ }^{*}$ Reprint requests to Dr A. K. Mukhopadhyay.
} 


\section{Materials and Methods}

The synthetic rat atriopeptin II (rAP-II, corresponding to ANF 103-123 according to Cantin \& Genest, 1985) was obtained from Sigma (Deisenhofen, FRG) and human chorionic gonadotrophin (hCG, 2nd International Standard Preparation) was generously provided by National Institute for Biological Standards and Control (Holly Hill, London, UK).

Preparation of luteal cells. Suspensions of bovine luteal cells were prepared by the method described by Brunswig et al. (1986). In brief, bovine ovaries from the local slaughterhouse were transported to the laboratory and the mid-luteal phase corpora lutea (stage 11), as judged by the criteria of Ireland et al. (1980), were dissected out. About $5 \mathrm{~g}$ tissue were minced with scissors and enzymically dispersed by incubation with collagenase $(3 \mathrm{mg} / \mathrm{ml})$ and DNAse $(20 \mu \mathrm{g} / \mathrm{ml})$ for $90 \mathrm{~min}$ at $37^{\circ} \mathrm{C}$ in $25 \mathrm{ml}$ minimum essential medium (Gibco Europe, Eggenstein, FRG) containing $25 \mathrm{mM}$-Hepes $\mathrm{pH} 7.4$ and $0.1 \%$ BSA (MEM). Dispersed cells were collected by centrifugation, washed twice with MEM and finally enriched by centrifugation on $63 \%$ Percoll. The number of cells was counted with a haemocytometer and cell viability, determined by the trypan blue exclusion test (Tennant, 1964), was $>80 \%$.

Incubation of luteal cells. A suspension of luteal cells $(200000 / 500 \mu \mathrm{l} \mathrm{MEM})$ was incubated at $37^{\circ} \mathrm{C}$ for $2 \mathrm{~h}$ in a shaking water bath with or without test substances. Incubation was terminated by the addition of $2 \mathrm{ml} 100 \%$ ethanol. The ethanol was evaporated and the residue was taken up in $500 \mu \mathrm{l} 0 \cdot 1 \% \mathrm{NaN}_{3}$. Cyclic AMP, cyclic GMP and progesterone were measured by radioimmunoassay as described previously (Budnik et al., 1987).

Guanylate cyclase assay. Guanylate cyclase was measured in a particulate fraction of luteal cells as described previously (Budnik et al., 1987). In brief the purified cell suspension was centrifuged at $90 \mathrm{~g}$ for $15 \mathrm{~min}$, homogenized in $10 \mathrm{~mm}$-Tris/ $\mathrm{HCl} \mathrm{pH} 7.5$ and $0.25 \mathrm{~mm}$-sucrose, sonicated (Branson Sonifier B 12) and centrifuged at $105000 \mathrm{~g}$ for $60 \mathrm{~min}$. The high-speed pellet was resuspended in $1.5 \mathrm{ml} 10 \mathrm{~mm}-\mathrm{Tris}-\mathrm{HCl} \mathrm{pH} \mathrm{7.5}$. Protein concentrations were determined by the method of Bradford (1976) using the reagents provided by BioRad Laboratories. The assay was performed in a total volume of $0.1 \mathrm{ml}$. The reaction mixture contained $10 \mathrm{~mm}$-Tris- $\mathrm{HCl} \mathrm{pH} \mathrm{7.5}$, creatine phosphate $(5 \mathrm{mM})$, creatine phosphokinase $(66 \mathrm{U} / \mathrm{ml})$, GTP $(2 \mathrm{mM})$, divalent cations as indicated and $5 \mu \mathrm{g}$ protein equivalent of particulate fraction. The incubation was carried out at $30^{\circ} \mathrm{C}$ for $20 \mathrm{~min}$ and was terminated by the addition of $1 \mathrm{ml}$ cold $100 \%$ ethanol. The cyclic GMP produced was extracted and measured by radioimmunoassay as described above (Budnik et al., 1987).

Radioimmunoassays. Progesterone was measured with a commercial kit supplied by RSL (Carson, CA, USA). According to the information provided with the kit the antibody had the following cross-reactions: $20 a$-dihydroprogesterone $5.41 \%$, desoxycorticosterone $3.80 \%$, corticosterone $0.70 \%$, 17-hydroxyprogesterone $0.67 \%$, pregnenolone $0.41 \%$, androstendione $0.23 \%$, testosterone $0.16 \%$, and oestrogens $0.01 \%$. The assay sensitivity, expressed as the minimum detectable amount, was $0.02 \mathrm{ng}$ progesterone $/ \mathrm{ml}$. The intra- and interassay coefficients were $4.9 \%$ and $7.6 \%$, respectively.

The cyclic nucleotides were measured with commercial assay kits provided by IBL (Hamburg, FRG). The cyclic AMP antibody cross-reacted $0.00028 \%$ with cyclic GMP, $0.00020 \%$ with adenosine, $0.00013 \%$ with $2^{\prime}, 3^{\prime}$-cAMP and $0.00001 \%$ with ATP and GTP. The antibody to cyclic GMP cross-reacted $0.001 \%$ with cyclic AMP, $0.0001 \%$ with GTP and $0.0001 \%$ with ATP. The detection limits of the assays were $5 \mathrm{fmol}$ cyclic AMP/tube and $7 \mathrm{fmol}$ cyclic GMP tube, respectively. The intra and interassay coefficients were, respectively, $<5 \%$ and $<10 \%$ for cyclic AMP and $5 \cdot 2 \%$ and $7.5 \%$ for cyclic GMP.

Statistics. Every incubation and enzyme assay was performed in triplicate if not otherwise stated and each experiment was repeated at least twice. Results are expressed as mean + s.e. Student's $t$ test was used throughout for statistical analysis.

\section{Results}

\section{Formation of cyclic GMP in luteal cells stimulated with $r A P-I I$}

The results summarized in Fig. 1 show that rAP-II was able to stimulate significantly cyclic GMP formation by bovine luteal cells in vitro. This stimulatory effect was dose-dependent and the maximally stimulating dose of rAP-II was $10 \mathrm{nM}$. For comparison, the amount of cyclic GMP measured in the cells incubated with $20 \mathrm{mi}$.u. hCG $/ \mathrm{ml}$ is also presented in Fig. 1. In previous experiments, hCG at this concentration stimulated significantly the production of progesterone and accumulation of cyclic AMP by bovine luteal cells. However, there was no increase in the amount of cyclic GMP formed in response to stimulation with hCG.

To examine whether this rAP-II-dependent stimulation was due to a stimulation of particulate guanylate cyclase activity, the enzyme activity in the membrane fraction prepared from bovine luteal cells in the presence or absence of $10 \mathrm{nM}-\mathrm{rAP}-\mathrm{II}$ was measured, with various concentrations 


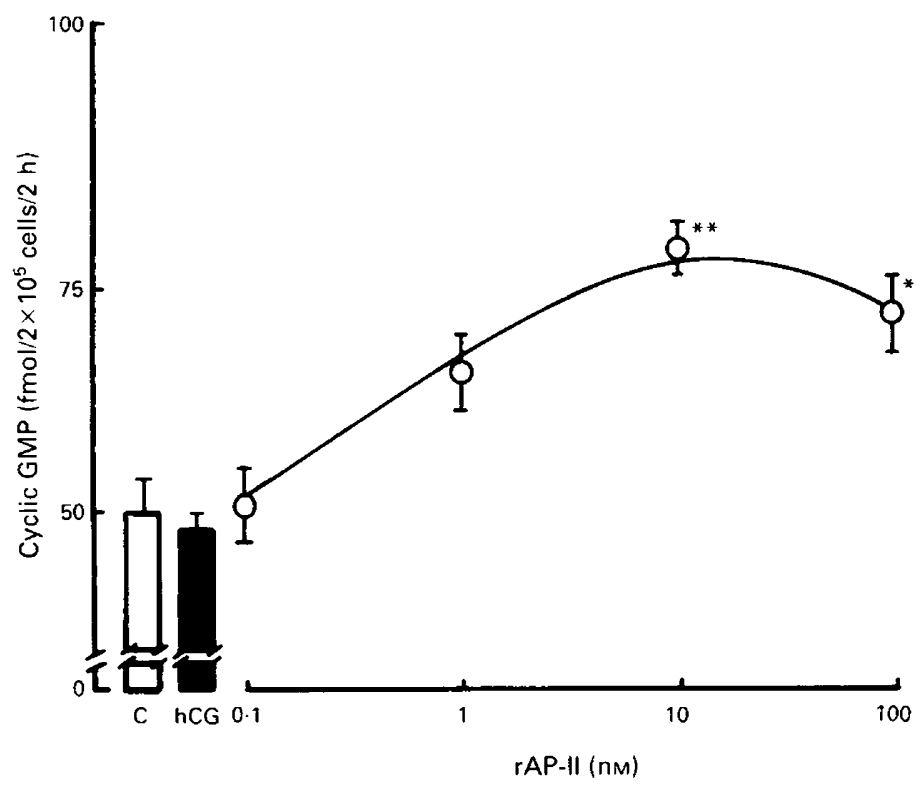

Fig. 1. Stimulation of cyclic GMP in a suspension of luteal cells ( 200000 cells $/ 500 \mu l$ medium) incubated without any addition (C), with $20 \mathrm{mi}$.u. hCG/ml (hCG) or with various concentrations of rAP-II $(O)$ for $2 \mathrm{~h}$ at $37^{\circ} \mathrm{C}$. Values are mean \pm s.e. for triplicate determinations. ${ }^{*} P<0.025,{ }^{* *} P<0.01$ compared with values for control incubations (C).
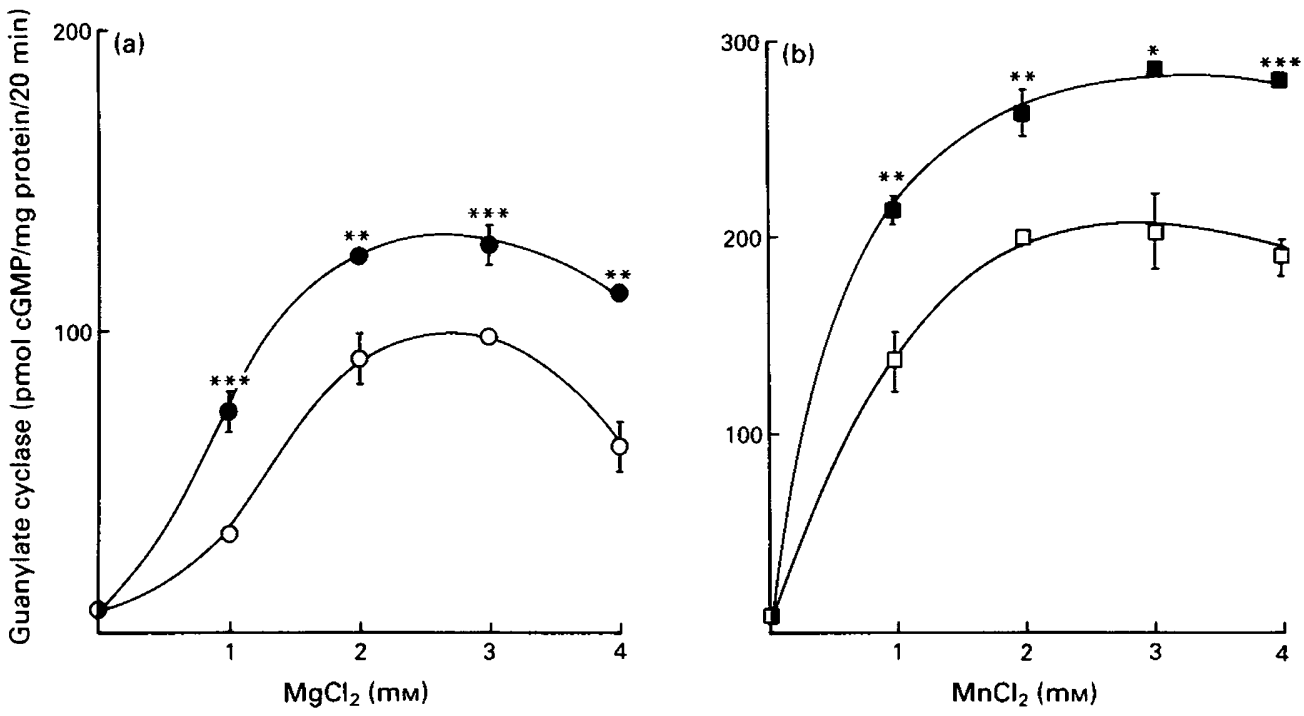

Fig. 2. Activation of particulate guanylate cyclase enzyme in bovine luteal cells by rAP-II in the presence of various concentrations of (a) $\mathrm{MgCl}_{2}$ or (b) $\mathrm{MnCl}_{2}$, without (open symbols) or with 10 nM-rAP-II (closed symbols). Values are mean \pm s.e. of triplicate determinations. ${ }^{*} P<0.05$, ${ }^{* *} P<0.01,{ }^{* * *} P<0.001$ compared with values without rAP-II. 
Table 1. Progesterone production by hCG-stimulated and unstimulated bovine luteal cells incubated in the presence of various concentrations of rAP-II

\begin{tabular}{lcrc}
\hline & \multicolumn{3}{c}{ Progesterone (ng/200000 cells/2 h) } \\
\cline { 2 - 4 } rAP-II & & \multicolumn{2}{c}{ hCG } \\
\cline { 2 - 4 }$(\mathrm{nM})$ & Basal & 2 mi.u./ml & 20 mi.u. $/ \mathrm{ml}$ \\
\hline 0 & $1.20 \pm 0.12$ & $9.20 \pm 0.61$ & $24.04 \pm 1.50$ \\
0.1 & $1.05 \pm 0.03$ & $8.93 \pm 0.83$ & $27.84 \pm 1.43$ \\
1 & $1.22 \pm 0.08$ & $10.01 \pm 1.21$ & $25.65 \pm 0.86$ \\
10 & $1.08 \pm 0.07$ & $8.89 \pm 0.27$ & $23.03 \pm 0.60$ \\
100 & $1.34 \pm 0.12$ & $9.33 \pm 0.07$ & $22.73 \pm 1.83$ \\
\hline
\end{tabular}

Values are mean \pm s.e. for quadruplicate determinations.

of $\mathrm{Mg}^{2+}$ (Fig. 2a) or $\mathrm{Mn}^{2+}$ (Fig. 2b) added. In the presence of rAP-II, a significant stimulation of guanylate cyclase activity occurred when each cation was present. In the absence of any cation the enzyme activity was close to the limit of detection of the assay. The enzyme activity measured in the presence of $\mathrm{Mg}^{2+}$ was only one-third of that measured in the presence of $\mathrm{Mn}^{2+}$.

\section{The effect of $r A P-I I$ on basal and $h C G$ induced steroidogenesis}

Luteal cells were incubated without or with hCG $(2 \mathrm{mi} . \mathrm{u} . / \mathrm{ml}$ or $20 \mathrm{mi} . \mathrm{u} . / \mathrm{ml})$ in the presence of various concentrations of rAP-II. The amounts of progesterone produced by the cells were measured. As shown in Table 1, hCG at both dose levels stimulated progesterone production significantly. However, there was no effect of rAP-II on basal or on hCG-stimulated progesterone production, regardless of whether a submaximal or maximal steroidogenic dose of hCG was used.

The amounts (mean \pm s.e.m.) of cyclic AMP accumulated (fmol $/ 2 \times 10^{5}$ cells $/ 2 \mathrm{~h}$ ) in luteal cells left untreated or stimulated with 2 or $20 \mathrm{mi} . \mathrm{u}$. hCG $/ \mathrm{ml}$ did not differ in the absence $(59 \pm 11$, $110 \pm 8$ and $539 \pm 17$ respectively) or presence ( $10 \mathrm{nM})$ of $\mathrm{rAP}-\mathrm{II}(93 \pm 19,90 \pm 17$ and $551 \pm 16$ respectively), although the effect of hCG was significant. When the phosphodiesterase inhibitor, 1 isobutyl-3-methyl xanthine (IBMX) was included in the incubation medium, rAP-II did not affect formation of progesterone or cyclic AMP in the absence or presence of hCG (data not shown).

\section{Discussion}

Specific receptor-mediated stimulation of progesterone secretion and cGMP accumulation by ANP in human granulosa cells has been reported (Pandey et al., 1987). In these cells ANP did not affect cAMP formation. On the other hand, we have reported previously that ANP markedly stimulates cyclic GMP formation by rat luteal cells through an activation of a particulate guanylate cyclase, without affecting progesterone or cyclic AMP formation (Budnik et al., 1987). In the present study, no effect of ANP on basal or hCG-stimulated cyclic AMP accumulation by bovine luteal cells was observed in the presence or absence of IBMX, although in mouse Leydig tumour cells (Pandey $e t$ al., 1985) and pituitary cells (Anand-Srivastava et al., 1985) an inhibition of cyclic AMP accumulation was reported. The atrial peptide also had no acute effect on steroidogenesis by bovine luteal cells. An effect of ANP on steroidogenesis and cAMP accumulation therefore appears to be specific to certain types of steroidogenic cells only. We have shown here that nanomolar concentrations of rAP-II can elicit a significant stimulation of cyclic GMP formation in bovine luteal cells. The maximally effective concentration was $10 \mathrm{nM}$, which is comparable to that reported for other tissues (Mukhopadhyay et al., 1986b; Budnik et al., 1987). The presence of ANP receptors in bovine 
corpus luteum has been demonstrated (Vollmar et al., 1988). Our results, showing that the particulate guanylate cyclase prepared from purified bovine luteal cells could be stimulated with rAP-Il measured in the presence of $\mathrm{Mg}^{2+}$ or $\mathrm{Mn}^{2+}$, corroborate the previous findings using total luteal tissue (Vollmar et al., 1988).

However, although bovine luteal cells can be included in among the target organs for atrial peptides, the physiological significance of this observation remains obscure. The fact that steroidogenesis by luteal cells was not affected by rAP-II would indicate that, if ANP has a function in the bovine corpus luteum, it does not appear to include the regulation of progesterone production.

We thank Professor F. A. Leidenberger and Dr H. Ch. Weise for support and encouragement; Ms U. Steuber for expert technical assistance; and Ms P. Stegemann for secretarial assistance.

\section{References}

Anand-Srivastava, M.B., Cantin, M. \& Genest, J. (1985) Inhibition of pituitary adenylate cyclase by atrial natriuretic factor. Life Sci. 36, 1873-1879.

Anderson, J.V. \& Bloom, S.R. (1986) Atrial natriuretic peptide: what is the excitement all about? J. Endocr. $110,7-17$.

Bex, F. \& Corbin, A. (1985) Atrial natriuretic factor stimulates testosterone production by mouse interstitial cells. Eur. J. Pharmacol. 115, 125-126.

Bradford, M.M. (1976) A rapid and sensitive method for the quantitation of microgram quantities of protein utilising the principle of protein-dye binding. Analyt. Biochem. 72, 248-254.

Brunswig, B., Mukhopadhyay, A.K., Budnik, L.T., Bohnet, H.G. \& Leidenberger, F.A. (1986) Phorbol ester stimulates progesterone production by isolated bovine luteal cells. Endocrinology 118, 743-749.

Budnik, L.T., Brunswig, B. \& Mukhopadhyay, A.K. (1987) Atrial natriuretic factor stimulates luteal guanylate cyclase. Regul. Peptides 19, 23-34.

Cantin, M. \& Genest, J. (1985) The heart and the atrial natriuretic factor. Endocrine Rev. 6, 107-127.

Ireland, J.J., Murphee, R.L. \& Coulson, P.B. (1980) Accuracy of predicting stages of bovine estrous cycle by gross appearance of the corpus luteum. J. Dairy Sci. 63, 155-160.

Kudo, T. \& Baird, A. (1984) Inhibition of aldosterone production in the adrenal glomerulosa by atrial natriuretic factor. Nature, Lond. 312, 756-757.

Mukhopadhyay, A.K., Bohnet, H.G. \& Leidenberger, F.A. (1986a) Testosterone production by mouse Leydig cells is stimulated in vitro by atrial natriuretic factor. FEBS Lett. 202, 111-116.

Mukhopadhyay, A.K., Schumacher, M. und Leidenberger, F.A. (1986b) Steroidogenic effect of atrial natriuretic factor in isolated mouse Leydig cells is mediated by cyclic GMP. Biochem. J. 239, 463-467.

Mukhopadhyay, A.K., Helbing, J. \& Leidenberger, F.A. (1988) Investigations on the role of $\mathrm{Ca}^{2+}$ in the mechanism of action of atrial natriuretic peptide in mouse Leydig cells. In Advances in Andrology, pp. 113-117. Eds A. F. Holstein, F. A. Leidenberger, K. H. Hoelzer \& G. Bettendorf. Diesbach Verlag, Berlin.

Pandey, K.N., Kovacs, W.J. \& Inagami, T. (1985) The inhibition of progesterone secretion and the regulation of cyclic nucleotides by atrial natriuretic factor in gonadotropin responsive murine Leydig tumor cells. Biochem. Biophys. Res. Commun. 133, 800-806.

Pandey, K.N., Pavlou, S.N., Kovacs, W.J. \& Inagami, T. (1986) Atrial natriuretic factor regulates steroidogenic responsiveness and cyclic nucleotide levels in mouse Leydig cells in vitro. Biochem. Biophys. Res. Commun. 138, 399-404.

Pandey, K.N., Osteen, K.G. \& Inagami, T. (1987) Specific receptor-mediated stimulation of progesterone secretion and cGMP accumulation by rat atrial natriuretic factor in cultured human granulosa-lutein (G-L) cells. Endocrinology 121, 1195-1197.

Racz, K., Kuchel, O., Cantin, M. \& DeLean, A. (1985) Atrial natriuretic factor inhibits the early pathway of steroid biosynthesis in bovine adrenal cortex. FEBS Lett. 192, 19-22.

Tennant, J.R. (1964) Evaluation of the trypan blue technique for the determination of cell viability. Transplantation 2, 685694.

Tremblay, J., Gerzer, R., Vinay, P., Pang, S.C., Beliveau, R. \& Hamlet, P. (1985) The increase of cGMP by atrial natriuretic factor correlates with the distribution of particulate guanylate cyclase. FEBS Lett. 181, 17-22.

Vollmar, A.M., Mytzka, C., Arendt, R.M. \& Schulz, R. (1988) Atrial natriuretic peptide in bovine corpus luteum. Endocrinology 123, 762-767.

Waldman, S.A., Rapoport, R.M. \& Murad, F. (1984) Atrial natriuretic factor selectively activates particulate guanylate cyclase and elevates cyclic GMP in rat tissues. J. biol. Chem. 259, $14332-14334$.

Received 18 November 1988 